tors' identities, coupled with blind submissions, can only have a salubrious effect on all aspects of the process and, more importantly, on all the individuals involved. The way things are routinely done now, we pander to the worst foibles of human character in the assumption that no other recourse is open to us. A more principled attitude would insist on creating the kind of professional ethos that places scholarly accountability as a cornerstone in the promotion of our goals as scholars.

Michael Shapiro

New York, New York

\section{Feminist Readings of Shakespeare}

To the Editor:

This letter responds to the attack by feminist critics in the January 1989 issue of $P M L A$ (77-78) on Richard Levin's piece on recent Shakespearean criticism ("Feminist Thematics and Shakespearean Tragedy," 103 [1988]: 125-38). As one who occasionally gives a course in Shakespeare and yearly teaches Romeo and Juliet in a survey course and who likes to keep up with critical debates, I found Levin's trenchant critique wonderfully informative as well as shrewdly deflating. This is precisely the type of analysis $P M L A$ should host: large topics of current concern written in simple, jargon-free language.

Then I received the January issue, in which some of the critics skewered in his essay ganged up to attack him. So far so good, but when I finished their diatribe and ad hominem assaults, which Levin had not resorted to in his essay, I found myself reacting indignantly. Talk about crude Aristotelianism! They acknowledge their own "partiality" of method and concept and then accuse him of believing in an outmoded distinction between genres as if it were astrology or belief in witches. They even attack at length his remark about appealing to rational minds for evidence. What else does $P M L A$ appeal to in its articles?

Finally, what I find insufferable is their thinly disguised religious fervor or totalitarianism, the idea that feminist assumptions cannot be subject to the usual methods of analysis and critique and that somehow $P M L A$, which serves a learned profession, should not allow critiques of fadist methods to be aired. I have been a member of the MLA for about twenty-five years and do not take kindly to this attack on what seemed to me a temperate-yes, rational and courageous-look at feminist readings of the tragedies. I only wish for more essays that examine the methods used by contemporary critics and that you and future editors will have the guts to print.

ARTHUR J. Weitzman

Northeastern University
To the Editor:

The Editorial Board ought to establish a policy of refusing to publish personal attacks in Forum. The penultimate sentence in the response to Richard Levin insults a distinguished scholar. Because one assumes that letters are scrutinized with some of the same care given to submissions, to print personal attacks on a scholar's career or character seems to lend them credence, however reasoned the victim's reply.

A policy should also insist that letters be free of misquotations and of obvious misreadings or distortions of the text in question. What is obvious, of course, is not always obvious. I thought the writers responding to Levin plainly wrong in asserting that he attacks all feminist criticism. But I am interested here less in that one response to Levin than in principles.

Treat letters like submissions. Have two members of the Editorial Board read each letter for its probity, fairness, and contribution to the issue. Inaccuracy and meanness are as reprehensible as sexist language. No more should they be tolerated.

DWIGHT H. PURDY

University of Minnesota, Morris

\section{To the Editor:}

The letter signed by twenty-four individuals reminded me of a course I used to give years ago-Argumentation and Debate-in which we discussed "The Seven Propaganda Devices." I could have used the letter to illustrate how these devices are employed-not very successfully-by the signatories.

1. Hasty Generalization. "We are puzzled and disturbed that Richard Levin has made a successful academic career by using the reductive techniques of this essay to bring the same predictable charges indiscriminately against all varieties of contemporary criticism" (paragraph 7).

2. Glittering Generalities. "He [Levin] fails to understand the serious concerns about inequality and injustice that have engendered feminist analyses of literature" (paragraph 2); "the energetic, cogent, sophisticated theoretical debate that is currently taking place within and among schools of Renaissance criticism" (paragraph 7) - a debate that Levin allegedly ignored; and "Levin does not recognize the profound challenges that feminist criticism poses to the crude Aristotelianism he has advocated since his introduction to his 1960 textbook, Tragedy: Plays, Theory, and Criticism" (paragraph 5).

3. Name Calling. Levin's essay is called "tired, muddled, unsophisticated" (paragraph 7).

4. Testimonial. Assuming that reference to the professors listed in paragraph 2 testifies to the worth of femi- 
nist scholarship, the signatories claim that Levin "ignores, mislabels, or marginalizes" the work of these feminist critics. All seven individuals are among the twenty-four signatories. Thus, what is presumably the objective "they" really becomes the subjective "we."

5. Stacking the Cards. "Accusing us of his own flaws, Levin paternally [as opposed to maternally?] tries to preempt our strengths by recommending our project to us as if it were his idea" (paragraph 4). The writers go on to itemize the particulars of the work they have been providing for over fifteen years. They then end the paragraph as follows: "But, absurdly, he wants us to provide these insights without revealing the strategies, structures, psychologies, and oppressiveness of the domination that particular male characters enact." While not quite an epiphany, that is quite a revelation!

6. Bandwagon. Just imagine, twenty-four signatories from places as diverse as Canada and England and a cross-section of American universities from Hawaii to Massachusetts-all attacking one sole professor.

7. Transfer. Just to make sure that the female feminist critics are not accused of ignoring male feminists, there are also four male signatories to "transfer" the implied approval of the opposite (opposing?) sex to what might otherwise be considered a sectarian ("sextarian"?) issue.

Incidentally, I thought that Richard Levin's reply was on target. Upon further reflection, since his cognomen means "lightning" the feminist letter and his response might be designated as "Donner und Blitz."

\section{MitTon Birnbaum}

\section{American International College}

\section{Reading Kenneth Burke}

\section{To the Editor:}

Robert McMahon's essay "Kenneth Burke's Divine Comedy: The Literary Form of The Rhetoric of Religion" (104 [1989]: 53-63) presents itself as a temporally new and textually current reading of Burke, even as it leans on Plato, Augustine, and Dante. I too value "the spirit, as well as the light, of Burke's achievement" but question the acceptability of McMahon's claim that his "essay examines the widening gyres of The Rhetoric of Religion." McMahon theoretically links what he calls a forward reading with backward movement in the generic form of divine as well as Platonist comedy: the dialectic union of "solemn comedy" with "tragic sacrifice," comedy's high seriousness as a low form of art. He makes this special claim for Burke: "He teaches us that politics and religion have long been and still are more deeply interconnected than our conventional categories lead us to think" (61). Having made similar, and earlier, claims for Burke, I would certainly have to agree.
Working at the intersection between religious conceptions and literary works, I have addressed some of the very same problems McMahon perceives, in antiquity as well as in the last four decades. For example, in All Things Vain: Religious Satirists and Their Art, published four years ago, I make five indexed references to Plato, twelve to Augustine, seven each to Dante and Burke. On beyond these ancients and moderns, no doubt much remains to be said concerning McMahon's large and important topics, which are still largely terra incognita. My concern in this letter is that the maps we have already in hand not get lost, or even smudged.

One of McMahon's first oxymoronic statements concerns Burke's religious secularity, what McMahon refers to as Burke's comical criticism of "the dogmatic willingness to anathematize an opposition as heretical" (53). I have myself made the theologically documented argument-with references to Leon Christiani's Heresy and Heretics, volume 36 in The Twentieth Century Encyclopedia of Catholicism, and to W. F. Cobb's "Abuse, Abusive Language" in the Encyclopedia of Religion and Ethics - that the intention of reforming ridicule is complicated by the orthodox Christian viewpoint that not everything about heresy is false. More than seventy years ago, long before Burke, F. M. Cornford demonstrated that comedy and tragedy have origins and sources that "lay . . . close together," however much they have drifted apart in the fullness of time. For Cornford, Comedy and Tragedy (his caps) are "two species of dramatic art," and he argues for "the supposition of a conscious rescue of Tragedy from its 'satyric' phase-a deliberate expulsion of those elements which distinguish the satyric drama from the tragic plays to which it was so closely linked" ("Comedy and Tragedy," The Origin of Attic Comedy, ed. Theodor H. Gaster, Garden City: Anchor-Doubleday, 1961, 165-91). I twice acknowledge Cornford and credit him for both "empirical though vast objectivity and subjective yet focused style." Remarking on what he calls "the comic program of The Rhetoric of Religion" (56), McMahon quotes Burke on the relation of satyr play to tragedy. Without a mention of Cornford, McMahon makes literary claims for Burke that look oblique, not to say derivative, on the subject.

McMahon claims that Burke imitates "the trinitarian structures of The Confessions" and that Burke has a "logological duel" with Augustine (56). Thirty years ago, in The Power of Satire: Magic, Ritual, Art, Robert C. Elliott's arguments, like his subtitle, were explicitly "trinitarian," and his two longest quotations from The Philosophy of Literary Form identified Burke's subtlety on tragedy and satire. Elliott's exposition seems to me clearer than McMahon's, which puts the case that "in Burke's sense satire is not properly comic" and that "Burke summons the spirit of solemn comedy to confront the spirit of tragic sacrifice" $(57,58)$. Here, what seem to be elusive are McMahon's discrete but connected mean- 